\title{
Are We Really Preparing Preservice Teachers to Teach with Technology in the Classroom?
}

\author{
Thierry Karsenti, Stéphane Villeneuve, \\ University of Montreal, Montreal, Canada \\ thierry.karsenti@umontreal.ca \\ University of Quebec in Montreal, Montreal, Canada \\ villeneuve.stephane.2@uqam.ca
}

\section{ABSTRACT}

Are Quebec's future teachers well prepared to integrate information and communication technologies (ICT) into the classroom? To answer this question, 2,065 teachers-in-training from nine universities offering teacher orientation training were surveyed. Results show that teachers-in-training have access to the equipment required to familiarize themselves with ICT and have largely mastered the basic technological tools. Moreover, they regularly and critically use ICT to plan, communicate, research information, prepare instructional materials, solve problems, and upgrade their professional skills. Despite this very optimistic picture, results also indicate that only a very small portion of teachers-in-training use ICT in the classroom. The study concludes with some recommendations.

\section{Council for Innovative Research}

Peer Review Research Publishing System

Journal: INTERNATIONAL JOURNAL OF COMPUTERS \& TECHNOLOGY

Vol 12, No. 9

editor@cirworld.com

www.cirworld.com, www.ijctonline.com 


\section{INTRODUCTION}

In 1995, there were slightly over 16 million Internet surfers around the world. Today there are more than 750 million. Western society has been hit by a technological maelstrom. In most industrialized countries, $50 \%$ of homes have an Internet-connected computer. Does the exponential presence of information and communication technologies (ICT) in our society herald a long-awaited revolution in education? Has the global knowledge society, promised since the 1970s, lauded in the 1980s, and anticipated in the 1990s with a mixture of respect, fear, and incredulity, become in the $21 \mathrm{st}$ century a vital reality in the teaching profession? Should ICT be part of teacher training programs? In Quebec, the rest of Canada, and all over North America and Europe, ICT have been largely integrated into primary and secondary schools. They have also become priorities in university teaching in all the industrialized countries. The hope is that ICT will provide better, more, faster, and more economical learning.

Unfortunately, education systems are facing a number of challenges. As noted by Bauer and Kenton (2005), despite the many studies in the last decade showing that ICT are effective learning tools, not all teachers use them regularly in the classroom. Nor do they integrate them into the curriculum. Is the fact that teachers make little use of ICT about to change? Will Quebec's teachers-in-training be well prepared to integrate information and communication technologies into the classroom in 2007? To answer this question, an extensive investigation was undertaken. The objective was to gain an overview of the level of mastery of one of the twelve professional competencies that teachers-in-training must acquire by completion of the education program: the ability to integrate information and communication technologies (ICT). The survey was conducted on 2,065 teachers-in-training enrolled in education programs at nine French-language universities in Quebec, Canada.

\section{BACKGROUND}

Why should we prepare teachers-in-training in the pedagogical use of ICT in the classroom? The reason is that, according to the recent literature, ICT clearly promote effective learning in many ways. Nevertheless, the literature also reveals that teachers decreasingly use ICT in the classroom. However, the debate is no longer about the necessity of integrating ICT into schools. Rather, it centres on the practicalities of how to integrate ICT into learning. The first section of this paper addresses the impact of ICT on effective student learning, followed by an analysis of the difficulties of integrating ICT into classroom teaching practices. Next, ICT in the training of future teachers in Quebec is briefly presented so that readers unfamiliar with Quebec's teacher training system can better grasp the context of the study and its results.

\section{Impact of ICT on effective learning}

Recent studies have demonstrated the potential of ICT to improve teaching and foster learning. The literature contains many reviews and meta-analyses, e.g., Schacter (1999), the thematic issue of Journal of Assisted Computer Learning, edited by [11], and more recently, the meta-analysis by [1]. These studies highlight the impacts of ICT on effective learning in terms of both quantity and quality.

For instance, in terms of quantity, [31] show that ICT significantly improve the quality of mother tongue skills. Apparently, ICT also improve overall writing skills, as well as the quality of project presentations and the amount of effort students expend to prepare texts [18; 22]. Studies by [21] as well as [3], [16], and [30;31] indicate that ICT positively impact standardized test scores among students, particularly in mathematics [21]. This is especially evident when ICT are used to solve mathematical problems, practice calculation skills, and explore mathematical relationships [8; 33].

The literature also contains descriptions of the more qualitative impacts of TIC on effective education. Studies by [12], [23; 24], [26], and others reveal that teachers and parents strongly believe that ICT positively impact effective education. There is also a school of thought that ICT positively impact students with learning difficulties [27]. Finally, much of the literature finds that ICT motivate learners, making the process more stimulating, particularly but not exclusively for students with learning difficulties. Thus, students put more effort into learning tasks [7; 27], are more conscientious in carrying out the tasks, and are less fearful of making mistakes [3]

\section{The difficult incursion of ICT into pedagogical practices}

Despite the evident impact on effective learning, the pedagogical use of ICT in schools remains an enormous challenge. The literature shows that ICT are barely used in classrooms [see $1 ; 2 ; 3 ; 10 ; 26 ; 16 ; 19 ; 21 ; 24 ; 34$ ]. This finding is pervasive throughout North America and Europe alike. Moreover, the findings of the 2004 OECD study Completing the Foundation for Lifelong Learning: An OECD Survey of Upper Secondary Schools reveal that the task of managing teaching hours and classroom organization combined with teachers' weak technological skills impedes any real ICT integration into teaching practices. The report highlights the disappointing use of ICT in education, despite substantial investments made in the last 20 years to equip schools. Expressing this disappointment, the report concludes that the instructional use of ICT in secondary schools is sporadic. It also notes that only a minority of teachers in the countries surveyed regularly use updated software. In an article published in the American Educational Research Journal, [19] noted, "Yet teachers are not well prepared to teach with the Internet, and its use is limited in scope and substance" (p. 447). [34] also found that introducing ICT into education did not obtain hoped-for results. The literature, including the recent reports by the OECD and [2], affirm that ICT are not consistently present in the classroom, a significant problem in a society facing an ICT maelstrom [1]. 


\section{ICT and the training of Quebec's future teachers}

To grasp the context for this study, a brief explanation of the role of ICT in Quebec's teacher-training system is required. In 2001, the ministère de l'Éducation du Québec (Quebec's education ministry) set up a frame of reference for teachers-intraining. Twelve professional competencies were established for teacher training under the four-year bachelor of education program. Firmly based on a philosophy of professionalism and a cultural learning approach, the guidelines aimed to improve training, with consequent higher student graduation rates, an issue in Quebec (over $30 \%$ of students do not complete high school).

Of the 12 competencies identified by the government, this study focuses on the pedagogical use of information and communication technologies (ICT) in teacher education programs: "Integrate ICT in the preparation and delivery of teaching/learning activities, and for instructional management and professional development purposes." There are six components to this competency. Thus, the teacher:

1. Exercises critical judgment regarding the real benefits and limitations of ICT as teaching and learning resources, and regarding the social issues they raise;

2. Assesses the instructional potential of computer applications and networking technology in relation to the development of the competencies targeted in the programs of study;

3. Communicates using various multimedia resources;

4. Uses ICT effectively to search for, interpret and communicate information and to solve problems;

5. Uses ICT effectively to build networks that facilitate information sharing and professional development with respect to his or her own field of teaching or teaching experience;

6. Helps students to familiarize themselves with ICT, to use ICT to carry out learning activities, to assess their own use of ICT, and to exercise critical judgment regarding the information they find on the Internet.

This description clearly indicates that teachers-in-training must appropriate ICT for planning, delivering lessons, and classroom management. Newly trained teachers must also be able to guide students in the use of ICT for better learning. All this is closely aligned with the overall mission of Quebec's education system, which is to provide instruction, socialize, and provide qualifications. Teachers must also use ICT as a learning tool for professional development. The stipulation to integrate ICT into professional development is a significant step forward in the ICT integration policy. Since the introduction of computers in the late 1960s, Quebec's educational system has advanced from teaching computers per se-or introducing learners (students and teachers-in-training) to the use of the computer, the Internet, and various computer tools- to integrating ICT for instructional purposes, following a cross-curricular approach.

\section{METHOD}

\section{Participants}

This study was funded by the ministère de l'Éducation, du Loisir et du Sport du Québec (Quebec's ministry of education, recreation and sports) (MÉLS). It was conducted at nine French-language universities in Quebec that offer education degrees. A total of 2,065 education students in the third and fourth years of the bachelor program participated in the study up to 2006. They had to pass each of the four years in the program, with practice teaching hours increasing in successive years. Third and fourth year students were selected for their lengthier classroom experience, particularly in teaching internships. Third-year students had completed about 60 days of teaching practice, and fourth-year students had completed up to 120 days. Thus, they had substantial experience with ICT.

\section{Measuring instruments}

To achieve the study objective of gaining an overview of the level of mastery of the professional competency, i.e. to integrate information and communication technologies, questionnaires were administered and group interviews were held. Questionnaires were divided into three sections: 1) general information; 2) general ICT skills; and 3) use of ICT for instructional purposes (during internships). The questionnaire comprised Likert-scale, closed-ended, and short-answer questions. Five group interviews were held with 34 participants to complete the data collection.

\section{Data analysis}

Statistical analyses were performed using SPSS 14.0 on the data obtained from the Likert-scale and closed-ended responses. Qualitative data obtained from the group interviews and short-answer responses to questionnaires were analyzed using N'Vivo and FileMaker Pro, respectively, following the content analysis approach recommended by [32]:

1. Transcription of short answers (questionnaires) and recordings (discussion groups)

2. Review and second review of short answers and recordings to identify significant passages

3. Grid coding, and emergence of new codes

4. Segment coding

5. Inverse coding to ensure proper segment coding 
6. Code comparison and condensation (surpercodes)

7. Preparation of tables and matrices.

\section{Results}

Certain results were subdivided into two categories: Teachers-in-training for primary and secondary schools. This was intended to highlight some interesting differences in the findings. In Quebec, both categories involve four years of university instruction, including several identical courses. However, separate teaching aspects are addressed. For example, the secondary program focuses more on specific subject areas (e.g., French, mathematics, sciences, etc.), while the primary program covers a wider variety of subjects (human sciences, French, natural sciences, etc.).

Results on access to technologies are presented first, followed by results on general technical skills. Second, study results are presented in relation to the research objective. Thus, in order to gain a more accurate picture of the professional competency of ICT integration, results are presented according to the six above-mentioned components.

\section{Teachers-in-training are more connected than average}

Results show that $98.8 \%$ of teachers-in-training enrolled in the primary education program (PEP) and $97.8 \%$ of those in the secondary education program (SEP) had access to a computer at home, and $92.1 \%$ (PEP: 93.3\%; SEP: $91.4 \%$ ) were connected to the Internet. This shows that Quebec's future teachers are more connected than the overall population of Quebec (68\%), Canada (66\%), and all Quebec university graduates (87\%), and slightly more connected than young adults from 18 to 24 years old $(97 \%)$.

\section{Strong basic software skills; development needed on more specific uses}

The data show that teachers-in-training have largely mastered the basic software that they regularly use at university and at home. On a 6-level Likert scale (none, beginner, fair, good, very good, excellent), over 95\% felt they were good or excellent at word processing, email, Internet navigation, and search engines. Moreover, over $70 \%$ felt they had mastered presentation software (good, very good, or excellent), while about $68 \%$ felt similarly qualified in the use of diverse communication tools (forum and chat). Nevertheless, results also illustrate that they were far less comfortable with other technological tools that would be highly useful for instructing and learning. For example, only $52 \%$ judged their ability to use a digital camera as above average. Only $43 \%$ had average mastery in the use of spreadsheets (e.g., Excel), which would be useful in teaching management as well as instructing subjects like mathematics and sciences. They were even less familiar with image-editing programs, video shoots, and Web page creation (respectively $29 \%, 23 \%$, and $14 \%$ judged their skills as above average).

\section{Components of the professional competency to integrate ICT}

In this section, results are presented according to the six components of the Quebec education competency. Data were obtained from questionnaires and group interviews.

Component 1. Critical judgment regarding ICT in a social context. The teacher-in-training must be able to develop a critical judgment of the relevance of using a given technology for instructional purposes. Thus, judgment must be used when integrating ICT. In addition, the teacher-in-training must be aware of the scope and presence of ICT in the daily lives of the students, and must know and understand Web content in order to guide students to perform relevant searches. The group interviews revealed that teachers-in-training appear to have developed good critical judgment regarding ICT. On the one hand, they realized the many benefits of integrating ICT into the classroom, mainly for instructional purposes (access to resources, class management, preparation of teaching materials, management and distribution of teaching materials, variation in teaching methods). They also mentioned the benefits for student learning (greater motivation, skills development potential, improved teacher-student relations, etc.). On the other hand, while appreciating the many benefits of the pedagogical integration of ICT, they were critical of the benefits of ICT as provided at the schools. They saw many challenges and problems inherent to the ICT themselves (insufficient, outdated, and unstable equipment; technical complications; time-consuming methods; more difficult class management) and the learning process (gap between students with and without home computers; focus on form over content; weak written language skills due to ICT). Furthermore, they were highly aware of the limitations of some information found on the Internet, and were ready to apply a variety of strategies to ensure that reliable information was downloaded (triangulation strategy, reliable sites, etc.). In the group interviews, some teachers-in-training also emphasized the potential for teenagers to become computer dependent. These positive results reveal that Quebec's future teachers generally develop good critical judgment regarding the use of ICT in schools. They feel that ICT are neither a panacea nor a detriment in the learning process. They have also developed a number of strategies to verify the authenticity of information found on the Internet.

Component 2. Increased use of email: disinterest in other communication tools. Results emphasize that teachers-intraining regularly use email to communicate. In fact, $65 \%$ of PEP and $74.3 \%$ of SEP students used email to contact colleagues almost daily, and in connection with their course work. This interesting result underscores the fact that ICT will henceforth be part of the daily lives of teachers-in-training. However, we must point out that email was much less used for communicating with students during internships (PEP: 18.2\%; SEP: $15.2 \%$ ) and with the students' parents (PEP: $4.7 \%$; SEP: $3.9 \%$ ), and that other communication tools such as forums and chat sites were little or not at all used for professional purposes (respectively $30.2 \%$ and $22.9 \%$ for PEP, and $39.2 \%$ and $27.1 \%$ for SEP). Why are forums less used? It appears that teachers-in-training have to juggle a multitude of tasks, and that they might prefer simple emailing because they are more comfortable with it. 
Component 3. Assesses the instructional potential of TIC to develop competencies: awareness needs improvement. Teachers-in-training must consider relevant instructional resources that are linked to the school program and critically choose appropriate software to ensure the best educational quality. Resources should allow students to develop their intellectual and relational skills. Results on the discussion groups show that teachers-in-training appear little inclined to use ICT to promote diverse skills development in students. They seemed aware of the benefits of ICT to facilitate learner access to resources and generate enthusiasm for learning, but only slightly aware of the potential of ICT to develop students' skills. However, during the group interviews, a respondent would occasionally underscore the potential of ICT to develop students' abilities to use information, solve problems, exercise critical judgment, and cooperate or communicate. Some also mentioned that ICT could help develop language skills (writing a variety of texts, revising texts, building vocabulary, etc.) and mathematical skills (solving problems, performing transformations, measuring areas and perimeters, finding a line of regression, etc.). Others maintained that a large variety of student skills could be developed using ICT. In sum, it appears that few teachers-in-training are able to assess the full educational potential of information and communication technology tools and networks for better learning and skills building. Therefore, this component of the professional competency to integrate ICT does not appear to have been fully mastered, and needs improvement.

Component 4. Heavy use of ICT to research information and solve problems. Communication is at the heart of the expression "information and communication technologies," and equally at the heart of the changes ICT have brought to education, more precisely, since the arrival of the Internet. Whether by email, discussion forums, or the creation of classroom websites, Internet communication enables hitherto non-existent and even unimaginable forms of exchange. Activities prepared by teachers-in-training must motivate students to seek online expertise to deepen or refine their learning. Some results in this study are highly encouraging in terms of teacher training and the teaching profession, particularly concerning the effective use of ICT to research, interpret, transmit information, and solve problems. Of the PEP and SEP students, 99.7\% and 99.3\% respectively used Internet research engines to seek information (see Figure 1). Thus, the Internet has become the primary information source for teachers-in-training.

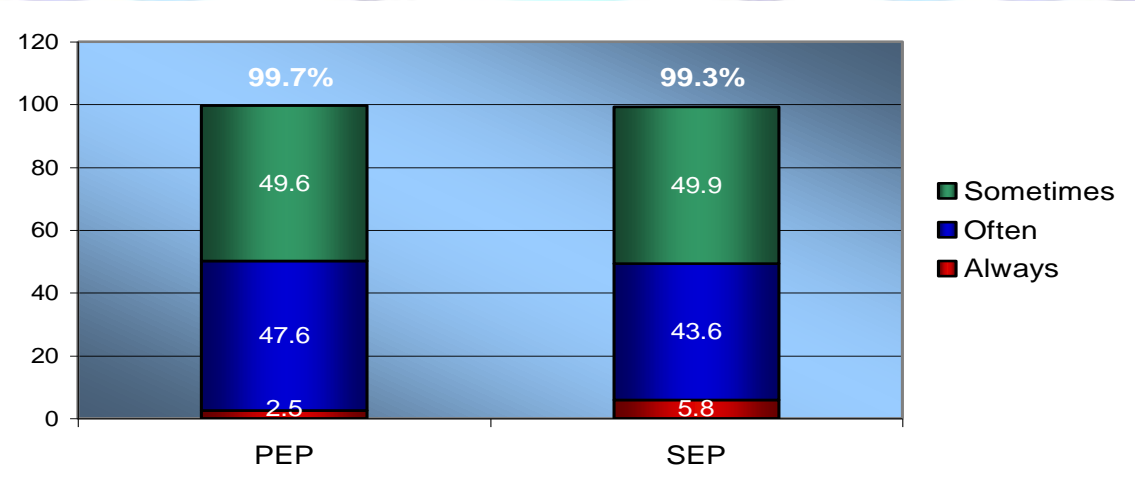

Fig 1: Percent uses of research engines to find information by primary and secondary school teachers-in-training.

Results were corroborated by the group interviews, revealing that a primary benefit of ICT was felt to be access to information. Access is simple, diversified, decentralized, open, and usually free. Besides enabling access to information that was formally difficult to find, ICT also facilitate knowledge sharing. Traditionally based on a philosophy of knowledge dissemination, teacher training must now incorporate the notion of knowledge navigation. With a growing number of teachers-in-training navigating the ever-expanding Internet universe, many expect to find at the university and in teachertraining programs the same speedy access to information via the Web. Far from remaining passive and waiting for knowledge to be delivered, they appear to be highly apt at Internet searches to find what they need. They also use ICT to keep in touch with their colleagues for mutual help, knowledge acquisition, and skills building. Results of this study show that they are evolving in a changing knowledge climate. At the university and in teacher training programs, learning is no longer received from just the instructor and the books. The Internet has become the primary information source. Thus, technologies are now a mandatory step in the knowledge acquisition process.

Component 5. Uses TIC for professional development? The fifth component involves using ICT for professional development. Teachers-in-training must be prepared to use ICT effectively to build exchange and continuous education networks in their teaching area and practices. Results show that $72 \%$ (PEP) and $72.9 \%$ (SEP) said they used ICT (i.e. Internet resources, teaching sites, official sites, and exchanges using ICT) for professional development. This reveals that they indeed use technologies, particularly communication tools, for professional development. Although this collaboration is sometimes limited to sharing internship experiences or requests for assistance, it is still important, since it allows them to develop skills that were not taught in their academic courses. Several studies have shown that a collaborative culture ensures teachers' professional development, as well as the effective implementation of any kind of scholastic reform [17]. Seeing that Quebec struggled for several years to implement its secondary school reform, could ICT serve as a catalyst for greater collaboration among teachers-to-be, thereby promoting effective education for a greater number of students?

Component 6. Guide students in the use of ICT at school. The sixth component is to guide students in the use of ICT to learn. However, results indicate that teachers-in-training use ICT mainly for lesson planning. Around 78\% (PEP: 79.5\%; 
SEP: $77.3 \%$ ) regularly used ICT to plan daily and/or weekly lessons (see figures 2 and 3). During the group interviews, one participant said that all lesson plans were prepared with a computer, since changes were easy to make. Other data from the group interviews indicate that they used ICT to prepare teaching materials, while some used the Internet to find images and relevant texts, ideas for educational activities, ready-made lesson plans, and so on.

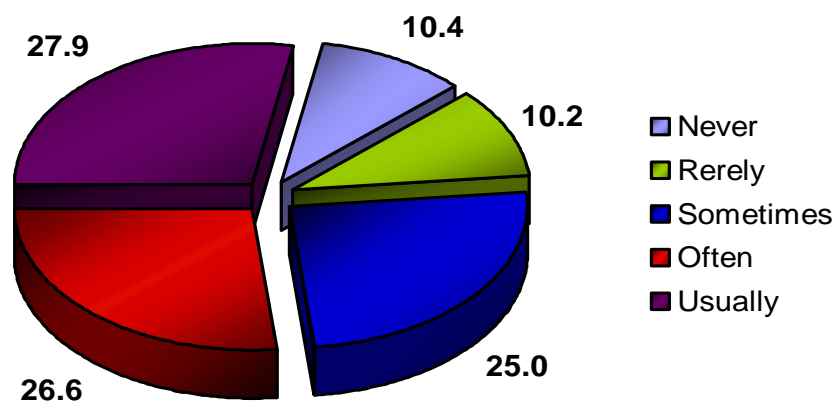

Fig 2: Percent uses of ICT to plan and prepare teaching-learning activities by primary school teachers-in-training.
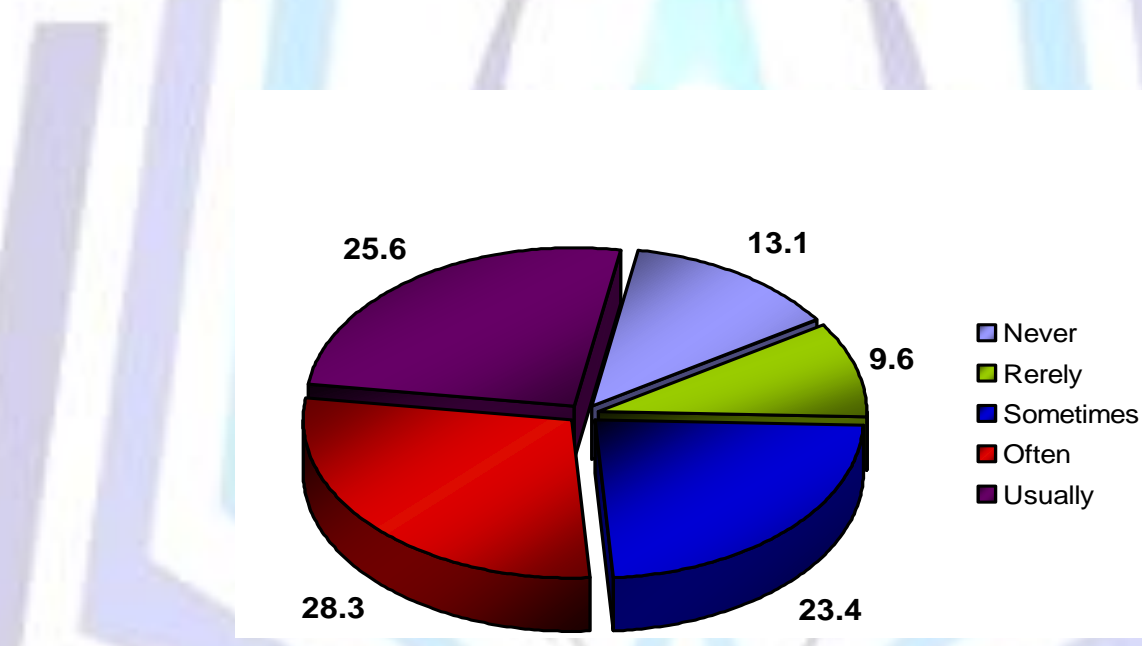

Fig 3: Percent uses of ICT to plan and prepare teaching-learning activities by secondary school teachers-intraining.

The least encouraging result of this study, and in line with the vast majority of international inquiry results in the field (see, e.g., the OECD inquiry, 2004), shows that technologies are still rarely used in the classroom by teachers-in-training, whether primary or secondary. In fact, barely $6.8 \%$ (PEP) said they regularly used ICT in class (Figure 4). This result is all the more disappointing because all of Quebec's primary schools have been connected to the Internet since 1999, and have been equipped with computers for many years. On top of that, in a good number of primary schools, computers are part of the curriculum, and have been a mandatory subject for several years. In secondary school, the results are less worrisome. Barely $15.6 \%$ of teachers-in-training said they used ICT regularly in the classroom (Figure 5). 


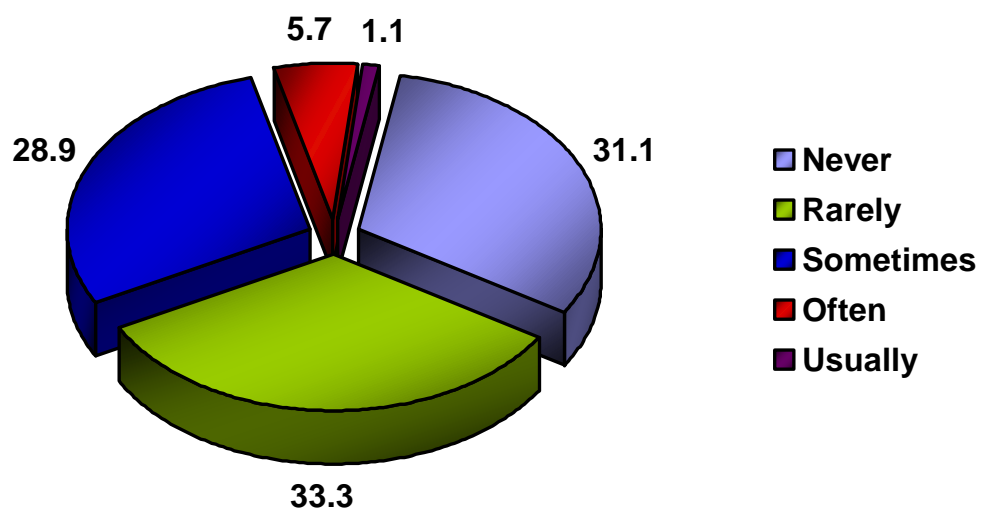

Fig 4: Percent uses of ICT in the classroom among primary teachers-in-training.
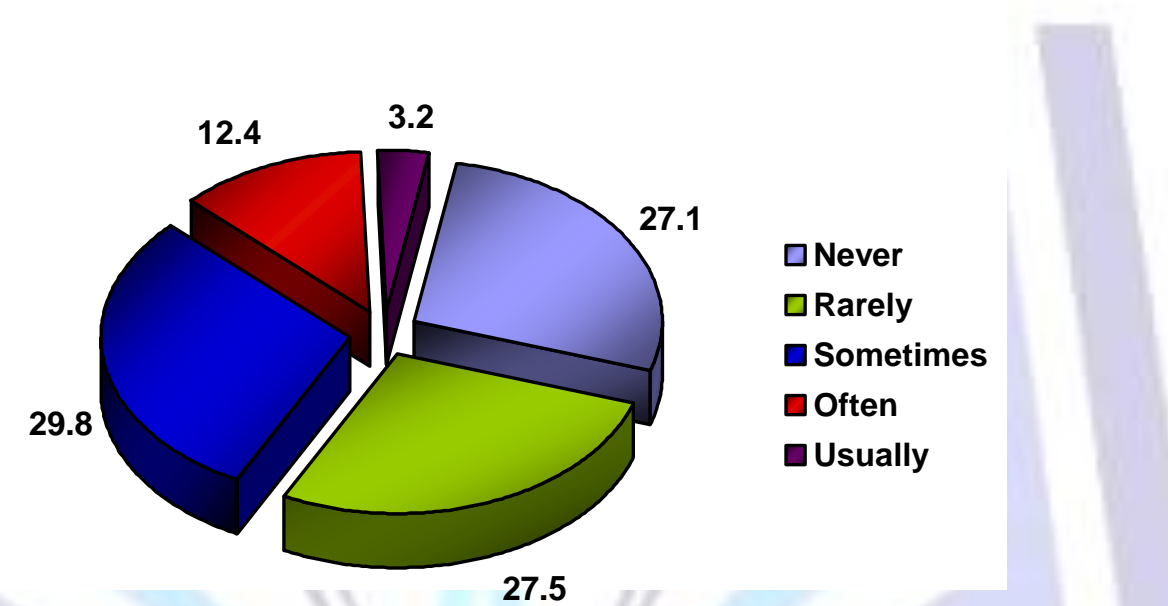

Fig 5: Percent uses of ICT in the classroom among secondary teachers-in-training.

This finding corroborates a very similar one by the OECD three years ago. Despite Quebec's investments in schools over the last 20 years, the use of computer technology in the classroom is still disappointing. The use of computer technology in the classroom for instructional purposes by the great majority of teachers-in-training having completed from 60 to 120 internship days in primary and secondary schools is still sporadic. In fact, only a minority of the participants regularly used ICT. However, a minority of participants did use ICT in a variety of ways: Internet research, presentations (using PowerPoint) on particular topics, images and videos, teaching a specific notion, and explaining the use of a tool that the students could use for themselves.

As to their ability to guide students in the use of ICT in class, results again show that the competency level is insufficient (Figure 8). Only $67.9 \%$ in the PEP category guided students in the use of ICT for educational purposes, and only $53.4 \%$ in the SEP category. This result is particularly challenging, given that technologies are increasingly part of our daily lives. Indeed, the CEFRIO study shows that over $97 \%$ of Quebec youth are connected to the Internet. It is therefore important that teachers are prepared to foster the instructional use of ICT at school. 


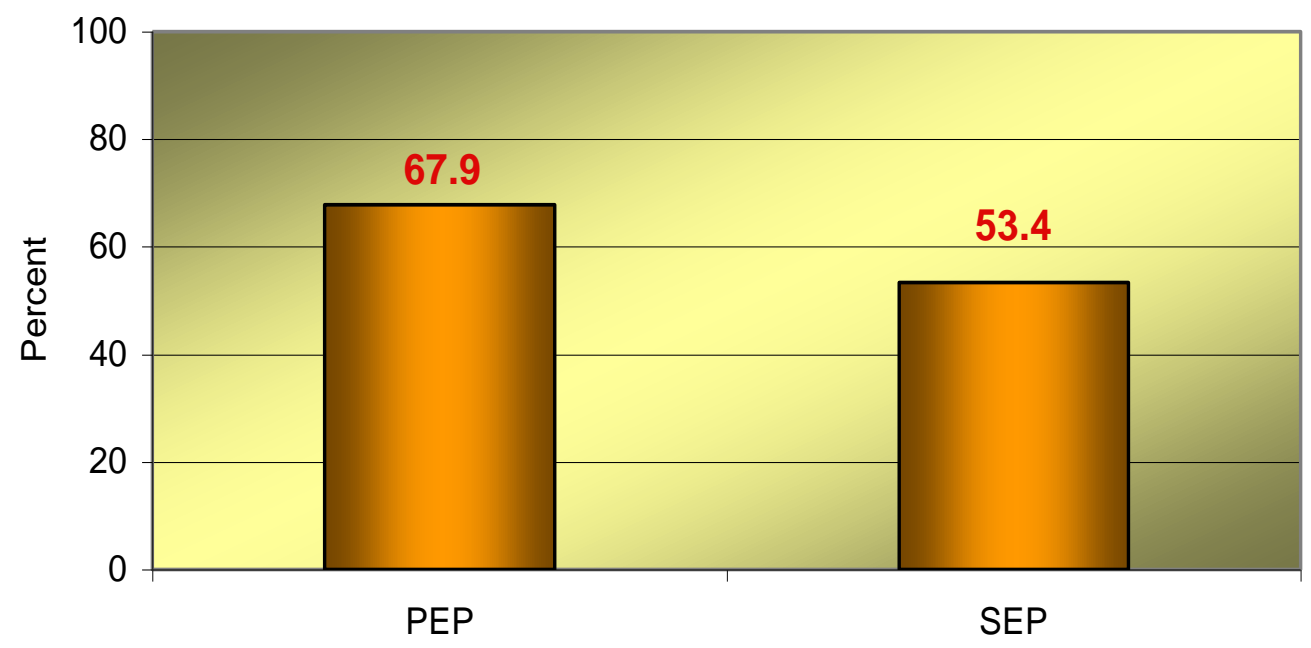

Fig 6: Proportion of primary education participants (PEP) and secondary education participants (SEP) that guided their students in the use of ICT at school.

Inferential statistical analyses were also performed to better grasp the factors liable to explain this low use of ICT in the classroom. The findings reveal that those who took an ICT integration course during the degree program $(M=2.79, E T=$ 0.96) were significantly more likely to guide students in the use of ICT than those who had not taken such a course $(M=$ 2.45, $E T=1.01), t(2021)=5,88, p<0.001$. When it came to preparing learning activities that used ICT, teachers who had taken the course $(M=2.63, E T=0.93)$ were significantly more likely to plan learning activities that used ICT than those who did not take the course $(M=2.30, E T=0.93), t(2032)=5.83, p<0.001$.

\section{CONCLUSION: WINNING CONDITIONS, AND CHALLENGES TO OVERCOME}

The first study finding is encouraging. The daily lives of teachers-in-training are increasingly impacted by ICT, since all, or almost all, participants had a personal computer with Internet access at home.

Overall results are encouraging in many respects. Although they concur with several studies [e.g., 4; 5; 28; 29] that underscore the basic technical skills of teachers-in-training to the detriment of their ability to integrate ICT in the classroom, results of the present study seem somewhat more promising. Quebec's future teachers have access to both the equipment they need to familiarize themselves with ICT and mastery of the basic tools. The data also indicate that they regularly and critically use ICT to communicate, research information, solve problems, and develop professionally. Although it is true that these factors are essential but insufficient for full pedagogical integration of ICT, they are still winning conditions, and a positive scenario in the near future may be contemplated.

Moreover, the results also reveal that a majority of teachers-in-training use ICT to plan and prepare teaching/learning activities, and although few in number, some of them guide students in the use of ICT for classroom activities. There is therefore substantial use of ICT among teachers-in-training, although it takes place mainly outside the classroom, and usually for communicating, planning lessons, and researching information. The majority have not effectively extended this external usage to the classroom.

Nevertheless, although classroom usage per se remains an enormous challenge, several interesting initiatives were noted, albeit isolated and sporadic. They could prove useful if circulated among other teachers-in-training. As the large majority use ICT to communicate and for professional development, videos showing peers using ICT in the classroom for instructional purposes could be rapidly distributed, and might inspire the adoption of similar teaching approaches.

The results also underscore the fact that education students who receive more training in the pedagogical use of ICT are more likely to plan ICT-assisted learning activities and guide students in the use of ICT in the classroom. Those who did not receive such training found it practically impossible to integrate ICT during their internship, since they had never really learned how.

Why do some of Quebec's future teachers receive so little training in the pedagogical integration of ICT, seeing that this competency is mandatory? This is a sensitive issue, but it still merits attention. From 1993 to 2001, Quebec's teachers-intraining were required to take one or more computer courses, where they learned such things as computer components and programming. Studies have shown that such courses have no impact on the pedagogical integration of ICT in classrooms. In 2001, based on the frame of reference for the competencies, some university education programs decided to eliminate these computer courses and replace them with courses on the pedagogical integration of ICT. Others decided to make ICT integration a transversal competency, to be incorporated across all the bachelor of education courses. Although this plan was the most promising in theory, in practice it was another story. 
Although the elimination of ICT courses was based on the rationale that educators would develop this competency through their own use of ICT, the results of the present study indicate exactly the opposite outcome. Under pressure of the new mandate, many university instructors began to use PowerPoint to teach. It was an accessible way to meet the new requirement to pedagogically integrate ICT as a transversal competency. Thus, for a variety of reasons, it appears that the primary ICT usage to which teachers-in-training were exposed was the automated PowerPoint slide presentation. And yet, this lecture-type instruction, which barely makes use of ICT, is not an effective teaching model for those who would like to integrate ICT into the classroom. Can PowerPoint slides used to teach a basic education course actually develop the ability to integrate ICT for teaching/learning purposes? The results of this study raise serious doubts on this. The responsibility for this lack in Quebec's teacher training system does not necessarily lie with the university instructors, who are not all specialists in the pedagogical integration of ICT. Should we blame the psychologists, linguists, and mathematicians for not having become specialists in this area under the new teacher training reform? Absolutely not, even though actions could have been taken at that level.

The problem lies with the universities that eliminated the ICT courses, and one thing is sure: lack of training in the pedagogical integration of ICT wields a direct impact on ICT use in the classroom by teachers-in-training. Unless practical courses on the pedagogical integration of ICT are reinstated or introduced, education students and teacher-training programs will be highly penalized. As it stands, the courses show education students how to use PowerPoint to present ideas in lecture form. However, the pedagogical integration of ICT in the classroom requires a range of competencies beyond delivering a lecture [see 15].

From the overall results, it is apparent that it is important for all education stakeholders, and especially those involved in teacher training, to work together to support our future teachers in the pedagogical integration of ICT, hence mastery of the professional competency to integrate ICT. Moreover, as recently pointed out by [14], schools take more time to absorb social changes, so this lag is no surprise, nor is it a cause for worry. The important thing may not be when ICT is introduced into the classroom, but rather the proper pedagogical use of ICT to achieve educational objectives (p.4). Whence the importance of instilling the pedagogical integration of ICT into the priorities of teacher-training programs and finding ways to regularly assess the progress made by teachers-in-training.

\section{REFERENCES}

[1] Balanskat, A., Blamire, R., \& Kefala, S. (2006). The ICT impact report. A review of studies of ICT impact on schools in Europe: European Schoolnet.

[2] Bauer, J., \& Kenton, J. (2005). Toward technology integration in the schools: Why it isn't happening. Journal of Technology and Teacher Education, 13(4), 519-546.

[3] Becta. (2006). The BECTA review 2006 - Evidence on the progress of ICT in education. Coventry, UK: Becta.

[4] Bennett, C., \& Daniel, L. (1999). Preparing novice teachers to use technology: Do they practice what we teach? Paper presented at the Proceedings of Society for Information Technology and Teacher Education International Conference.

[5] Brinkerhoff, J., Ku, H., Glazewski, K., \& Brush, T. (2001). An assessment of technology skills and classroom technology integration experience in preservice and practicing teachers.

[6] CEFRIO. (2007). Netendances 2006 : Évolution de l'utilisation d'Internet au Québec depuis 1999. Montréal.

[7] Christmann, E. P., \& Badgett, J. L. (2003). A meta-analytic comparison of the effects of computer-assisted instruction on elementary students' academic achievement. Information Technology in Childhood Education Annual, 2003(1), 91104.

[8] Clements, D. H. (2000). From exercises and tasks to problems and projects - Unique contributions of computers to innovative mathematics education. The Journal of Mathematical Behavior, 19(1), 9-47.

[9] Conseil supérieur de l'éducation. (1991). La profession enseignante: vers un renouvellement du contrat social. Québec: Presses du Gouvernement du Québec.

[10] Cox, F. (2003). The digital divide: Opportunities for information literacy. Paper presented at the Society for Information Technology and Teacher Education International Conference 2003.

[11] Cox, M. J. (2002). Information and communication technologies: Their role and value for science education. In M. M. J. Osborne (Ed.), Good Practice in Science Teaching - What Research has to Say. London: Routledge.

[12] ITU. (2004). Annual report. Norway: Network for IT-Research and Competence in Education

[13] Karsenti, T. (2005). Développer le professionnalisme collectif des futurs enseignants par les TIC : bilan de deux expériences réalisées au Québec. Recherche et formation, 49, 73-90.

[14] Karsenti, T., \& Gauthier, C. (2006). Les TIC bouleversent-elles réellement le travail des enseignants? Formation et profession, 12(3), 2-4.

[15] Karsenti, T., \& Larose, F. (2005). L'intégration pédagogique des TIC dans le travail enseignant : recherches et pratiques. Québec: Presses de l'Université du Québec.

[16] Kessel, v. N., et al. (2005). ICT education monitor: Eight years of ICT in schools. Netherlands: Ministry of Education, Culture and Science. 
[17] Kluth, P., \& Straut, D. (2003). Do as we say and as we do: Teaching and modeling collaborative practice in the university classroom. Journal of Teacher Education, 54(3), 228-240.

[18] Lewin, C., Scrimshaw, P., Mercer, N., \& Wegerif, R. (2000). The KS1 literacy evaluation project using low cost computers. Coventry, UK: Becta.

[19] Mc Crory Wallace, R. (2004). A framework for understanding teaching with the Internet. American Educational Research Journal, 41(2), 447-488.

[20] Ministère de l'Éducation. (2001). La formation à l'enseignement : les orientations, les compétences professionnelles. Québec: Ministère de l'Éducation.

[21] OCDE. (2004). Completing the foundation for lifelong learning: An OECD survey of upper secondary schools: OECD.

[22] Passey, D. (2000). Developing teaching strategies for distance (Out-of-School) learning in primary and secondary schools. Educational Media International, 37(1), 45-57.

[23] Ramboll Management. (2005). Evaluation of ITMF: Overall results. Copenhagen: Ramboll Management.

[24] Ramboll Management. (2006). E-learning Nordic 2006. Impact of ICT on education. Copenhagen: Ramboll Management.

[25] Schacter, J. (1999). The impact of education technology on student achievement: What the most current research has to say.

[26] Schoolnet, E. (2004). ERNIST ICT schoolportraits: European Communities.

[27] Sivin-Kachala, J., \& Bialo, E. R. (2000). 2000 research report on the effectiveness of technology in schools (7th ed.). Washington, DC: Software \& Information Industry Association.

[28] Swain, C. (2004). They can talk the talk but will they walk the walk?

[29] Swain, C. (2006). Preservice teachers self-assessment using technology: Determining what is worthwhile and looking for changes in daily teaching and learning practices. Journal of Technology and Teacher Education, 14(1), 29-59.

[30] Underwood, J., et al. (2005). Impact of broadband in schools. Nottingham, UK: Becta.

[31] Underwood, J., et al. (2006). ICT test bed evaluation - Evaluation of the ICT test bed project. Nottingham, UK: Trent University.

[32] Van der Maren, J.-M. (1995). Méthodes de recherche pour l'éducation (2e ed.). Montréal: Les Presses de l'Université de Montréal.

[33] Yelland, N. (2003). Young children learning with Logo: An analysis of strategies and interactions. Journal of Educational Computing Research, 9(4), 465-486.

[34] Zhao, Y., \& Frank, K. A. (2003). Factors affecting technology uses in schools: An ecological perspective. American Educational Research Journal, 40(4), 807-840. 